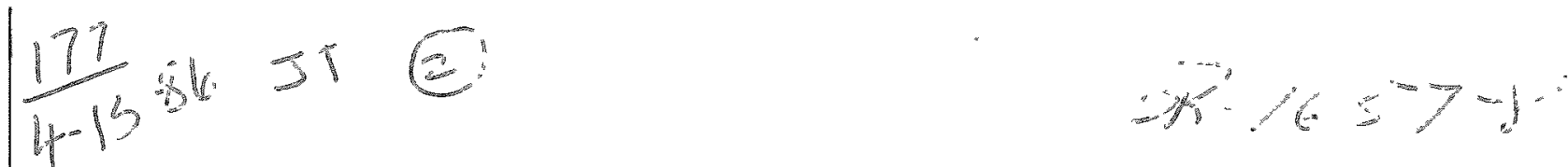

\title{
Stress Relaxation of Cellular Silicone Material: 1984
}

Bendix Kansas City Division

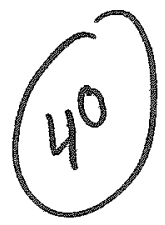

J.W. Schneider

BDX-613-3420

Published March 1986

Topical Report

Prepared for the United States Department of Energy Under Contract Number DE-AC04-76-DP00613.

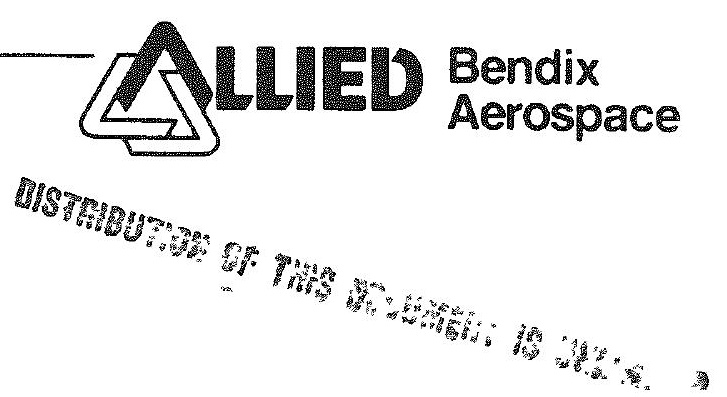


$\frac{15}{1586} 51$

\section{Stress Relaxation of Cellular} Silicone Material: 1984

Bendix Kansas City Division

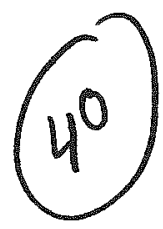

J.W. Schneider

$B D X-613-3420$

Published March 1986

Topical Report

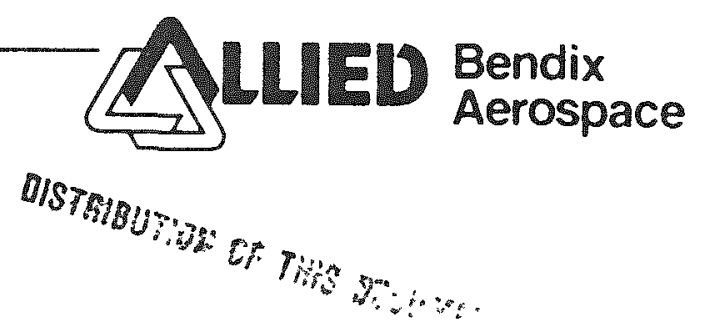




\section{DISCLAIMER}

This report was prepared as an account of work sponsored by an agency of the United States Government. Neither the United States Government nor any agency Thereof, nor any of their employees, makes any warranty, express or implied, or assumes any legal liability or responsibility for the accuracy, completeness, or usefulness of any information, apparatus, product, or process disclosed, or represents that its use would not infringe privately owned rights. Reference herein to any specific commercial product, process, or service by trade name, trademark, manufacturer, or otherwise does not necessarily constitute or imply its endorsement, recommendation, or favoring by the United States Government or any agency thereof. The views and opinions of authors expressed herein do not necessarily state or reflect those of the United States Government or any agency thereof. 


\section{DISCLAIMER}

Portions of this document may be illegible in electronic image products. Images are produced from the best available original document. 


\title{
STRESS RELAXATION OF CELLULAR \\ SILICONE MATERIAL: 1984
}

\author{
By J. W. Schneider
}

Published March 1986

\section{DISCLAMMER}

This report was prepared a an account of wonk spugacored by an agency of the Unied States

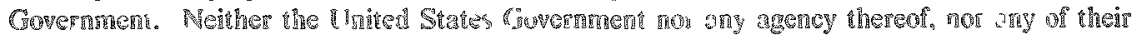

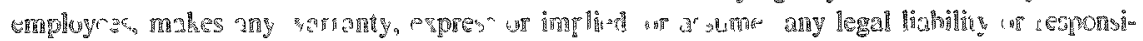

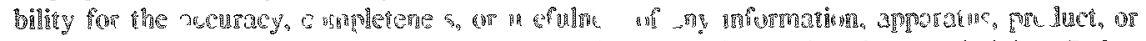

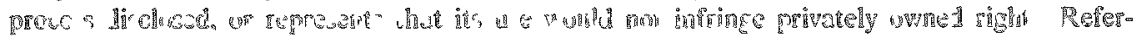

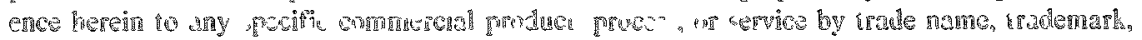

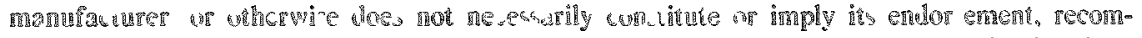

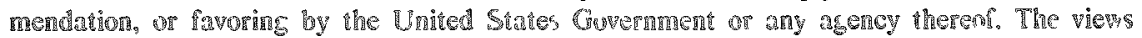
and opinon of authers expressed herein do not necessarily tate or reflect those of the Unied States Government or any agency thereof. 
STRESS RELAXATION OF CELLULAR SILICONE MATERIAL: 1884

BDX-613-3420, Topical Report, Published March 1986

Prepared by J.W. Schneider

The long-term ( 10 years) stress relaxation properties of cellular silicone materials at room temperature are under evaluation. Both equilibrium (random copolymer) and condensation- (block copolymer) type base polymers are included. The equilibrium-type material used urea as the leachable filler, and the condensationtype material used ammonium chloride. Each material was compounded to yield densities of 0.34 and $0.52 \mathrm{~g} / \mathrm{cm}^{3}$ for thicknesses of $1.17,1.52$, and $2.54 \mathrm{~mm}$. These density-thickness combinations were compressed to nominal compressions of 20 and 40 percent with nine replicates at each condition. A specially designed fixture was used to maintain a specific compression on the cellular sample, and a universal test machine acquired the load data. Currently, the predicted load retention is between 60 and 68 percent of the original load.

$D C: j a d$

DTR96/c 


\section{CONTENTS}

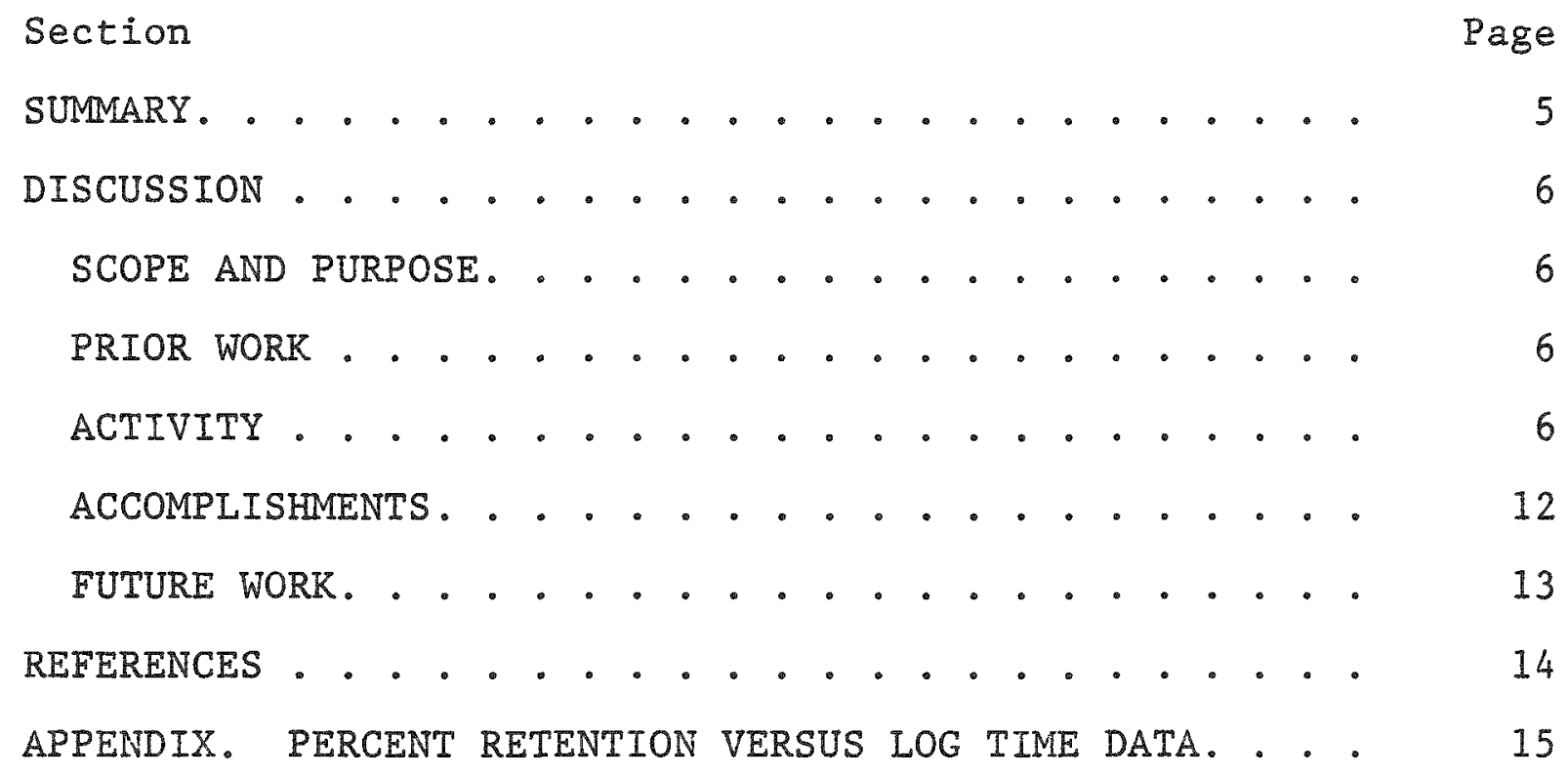




\section{ILLUSTRATIONS}

Figure

Page

1

Cross Section of Compression Fixture With Specimen Compressed to Thickness A....

Compression Fixture for Aging of Material. .

Typical Loading and Unloading Curves, Normal Scale, at Initial Loading and Later Testing. . . . . . . . . . . .

Typical Loading and Unloading Curves, Expanded Scale With Tangent Drawn, at Initial Loading and Later Testing. . . . . . . . . .

Percent Retention Versus Log Time for Equilibrium-Type Material, $0.34 \mathrm{~g} / \mathrm{cm}^{3}$ Nominal Density. . . . . . . . . .

Percent Retention Versus Log Time for Condensation-Type Material, $0.34 \mathrm{~g} / \mathrm{cm}^{3}$

Nominal Density. . . . . . . . . .

$A-3$

Percent Retention Versus Log Time for Equilibrium-Type Material, $0.52 \mathrm{~g} / \mathrm{cm}^{3}$ Nominal Density. . . . . . . . . .

Percent Retention Versus Log Time for Condensation-Type Material, $0.52 \mathrm{~g} / \mathrm{cm}^{3}$ Nominal Density. . . . . . . . . .

Percent Retention Versus Log Time, Comparison of Materials . . . . . . . . . . .

\section{TABLES}

Number 


\section{SUMMARY}

The long-term ( 10 years) stress relaxation properties of celiular silicone materials formed with urea and ammonium chloride as the leachable fillers are being evaluated. Two types of base polymers were used in the test: equilibrium-type (random copolymer) with urea, and condensation-type (block copolymer) with ammonium chloride. Each material was compounded to yield densities of 0.34 and $0.52 \mathrm{~g} / \mathrm{cm}^{3}$. Three sample variations of $1.17,1.52$, and $2.54 \mathrm{~mm}$ nominal thickness were prepared from the lower density product, and two sample variations of 1.52 and $2.54 \mathrm{~mm}$ nominal thicknesses were prepared from the higher density product. Each of the material/thicknesses combinations was compressed to 20 and 40 percent, with nine replicates at each condition. Of these nine samples, two were 3-year controls, two are 10-year controls, and five are tested yearly.

A specially designed compression fixture for aging maintained a specific compression on the cellular sample at room temperature, and a universal test machine was used to acquire the load data. The load was recorded at initial assembly and at selected times thereafter. In all, a total of 180 specimens are in test: 90 equilibrium type material samples that have been stored approximately 9 years and 90 condensation type material samples that have been stored for 8 years.

The current data still support the statement that the time-dependent loss of load-bearing properties is approximately log-linear. The major differences are between the material types and the two densities of each material type. At the end of the 10-year study, the projected load retention of all samples will be between 60 and 68 percent of original load. The condensation-type material is expected to be the superior material. 


\section{DISCUSSION}

\section{SCOPE AND PURPOSE}

Cellular silicone cushions serve several functions. They fill gaps between components; they compensate for manufacturing tolerances of adjacent components; and they allow for thermal expansion of the components. For the cushions to be able to perform this job, they are required to exert a specific compressive force at predetermined maximum and minimum gaps. Because the cellular silicone cushion must do this job of gap filling for the stockpile life of the weapon, the purpose of this project was to gather information about the long-term stress behavior of the cushion under load.

\section{PRIOR WORK}

Background on this project has been reported. ${ }^{-5}$ Each report has included an additional year's data.

\section{ACTIVITY}

The aging fixtures used in this study are compatible with a universal test machine. Each cushion sample was aged in its own fixture. A cross section is shown in Figure 1; Figure 2 shows actual views of the fixture. With the fixture installed on the test machine, the load bearing properties of the material can be checked at selected time intervals. The assembled aging fixture on the left side in Figure 2 has a threaded stud that screws into the actuator rod of the test machine. The six nuts and bolts also seen in this view maintain the clamping force on the cushion sample during aging. The four cap screws in this view hold a removable detail (plug) that can be changed to vary the amount of compression placed on the sample. This cavity and cushion sample can be seen in the right hand view of Figure 2.

A total of 180 specimens are in test: 90 equilibrium-type (random copolymer) samples (material in use now) that have been stored approximately 9 years and 90 condensation-type (block copolymer) samples (material for future use) that have been stored approximately 8 years. Each type of material was compounded to yield nominal apparent densities of 0.34 and $0.52 \mathrm{~g} / \mathrm{cm}^{3}$. The equilibrium-type material used urea as the leachable filler, while the condensation-type material used ammonium chloride. Three sample variations of $1.17,1.52$, and $2.54 \mathrm{~mm}$ nominal thicknesses were prepared from the lower-density product, and two sample variations of 1.52 and $2.54 \mathrm{~mm}$ nominal thicknesses were prepared from the higher-density product. Each 


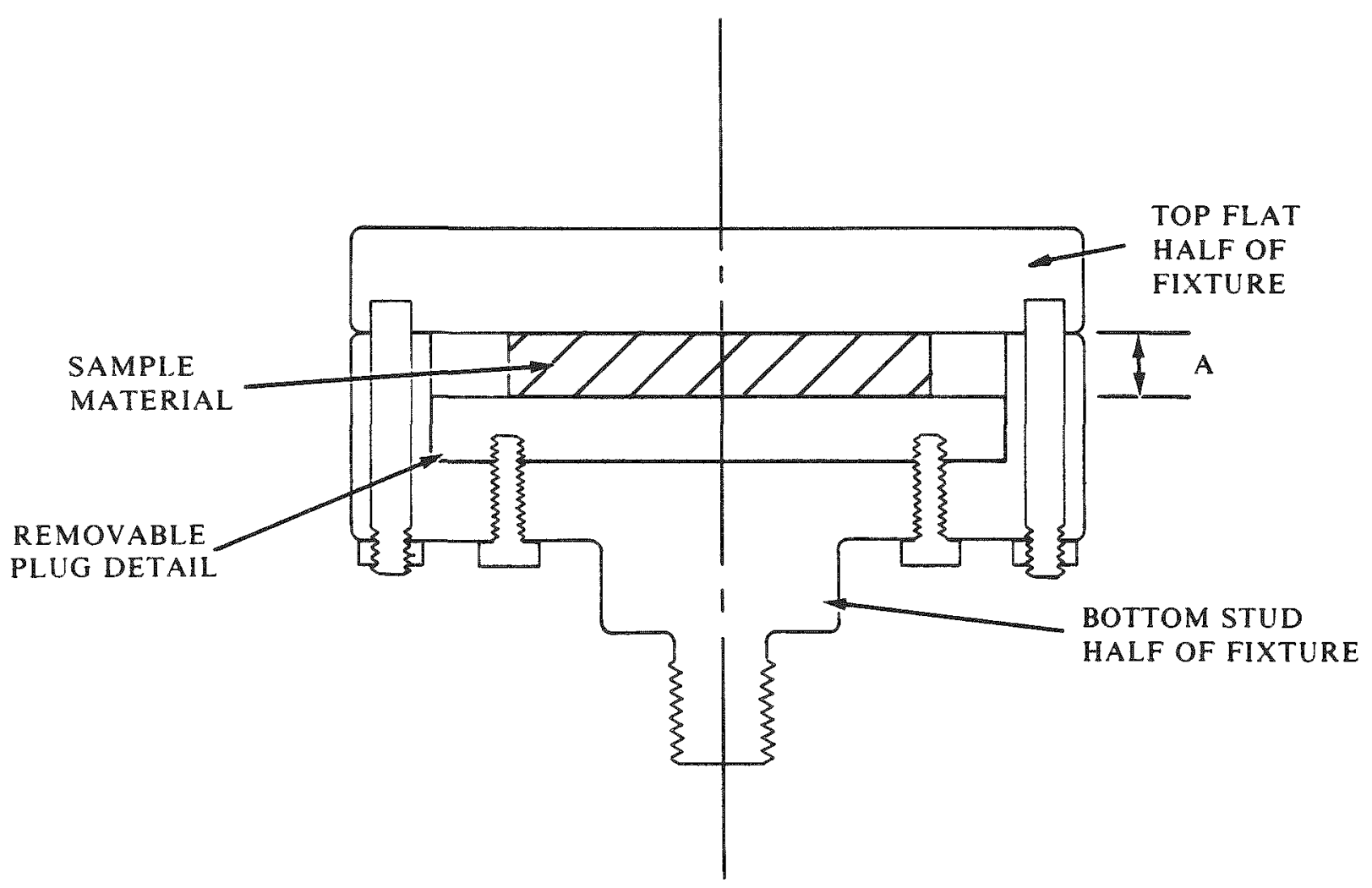

Figure 1. Cross Section of Compression Fixture With Specimen Compressed to Thickness A

of the material/thickness combinations was compressed to nominal compression of 20 and 40 percent. There are nine replicates at each condition: five are tested yearly, two are 3-year controls, and two are 10-year controls.

The initial procedure for testing was to place the lower half (stud side) of the fixture into the load frame and to place a $50.8-\mathrm{mm}$-diameter disc of cushion (sample material) in the center of the cavity. The remaining half of the fixture was aligned and set on the sample. A small controlled amount of preload was applied to maintain contact between the fixture and the test machine load cell.

Force was the feedback variable in this test; increasing force on the fixture was applied at a constant rate up to and beyond fixture closure. At this point, the loading was reversed until the preload was the only force, and the unloading was reversed to return the fixture well beyond fixture closure. Then, the 
unloading-loading sequence was repeated. Holding the load at this point, the six retaining nuts were placed back on the fixture to maintain this compression on the cushion sample until the sample was checked again. The fixture was then removed, and a new fixture could be assembled. Typical results from the initial assembly testing are shown in the upper set of curves in Figure 3.

The lower set of curves in Figure 3 is a typical result of later testing. The testing sequence in this case was identical to that of the assembly steps, with the exception of the starting point. Assembled fixtures were placed in the load frame, and a force greater than the closing force was applied. The six retaining nuts were loosened and removed, and the test continued in the same manner as before. The sample was cycled six times (three cycles at one amplification and three cycles at another higher amplifications which are used for either load retention or effective compression set results) and then was locked up until the next testing.

Two pieces of information were available from the two sets of curves. One was the force exerted by the sample at fixture closing. The second was the sample thickness at minimum load (preload), at both initial loading and later testing.

Figure 3 shows that determining the closure load with any precision is difficult. For this reason, the actual measurement was obtained by using an amplified displacement scale (Figure 4). As before, the upper curve is the assembly loading and the lower set the aged loading. To determine the closure load, a line tangent to the loading curve, between 0.025 and $0.0025 \mathrm{~mm}$ prior to closure, was drawn, and its intersection with the vertical closure line was read. By dividing the value obtained for the aged sample by the value obtained for the initial assembly load, $a$ percent (load) retention was calculated. These data are plotted versus the log of the time in assembly in Figures $A-1$ through A-4 in the Appendix. All the data points were used to determine a least-squares approximation for each material type and density. The least-squares semi-log curve fit used the equation

$\mathrm{Y}=\mathrm{A} * \operatorname{EXP}(\mathrm{B} * \mathrm{X})$,

where

$A, B=$ constants generated by the program;

$Y=$ time, and

$\mathrm{X}=$ percent load retention.

For the equilibrium-type material at $0.34 \mathrm{~g} / \mathrm{cm}^{3}$, the fit predicts a 10-year percent load retention of 61.36. Visually, the straight line generated did not fit the data we11. A second equation was tried. 


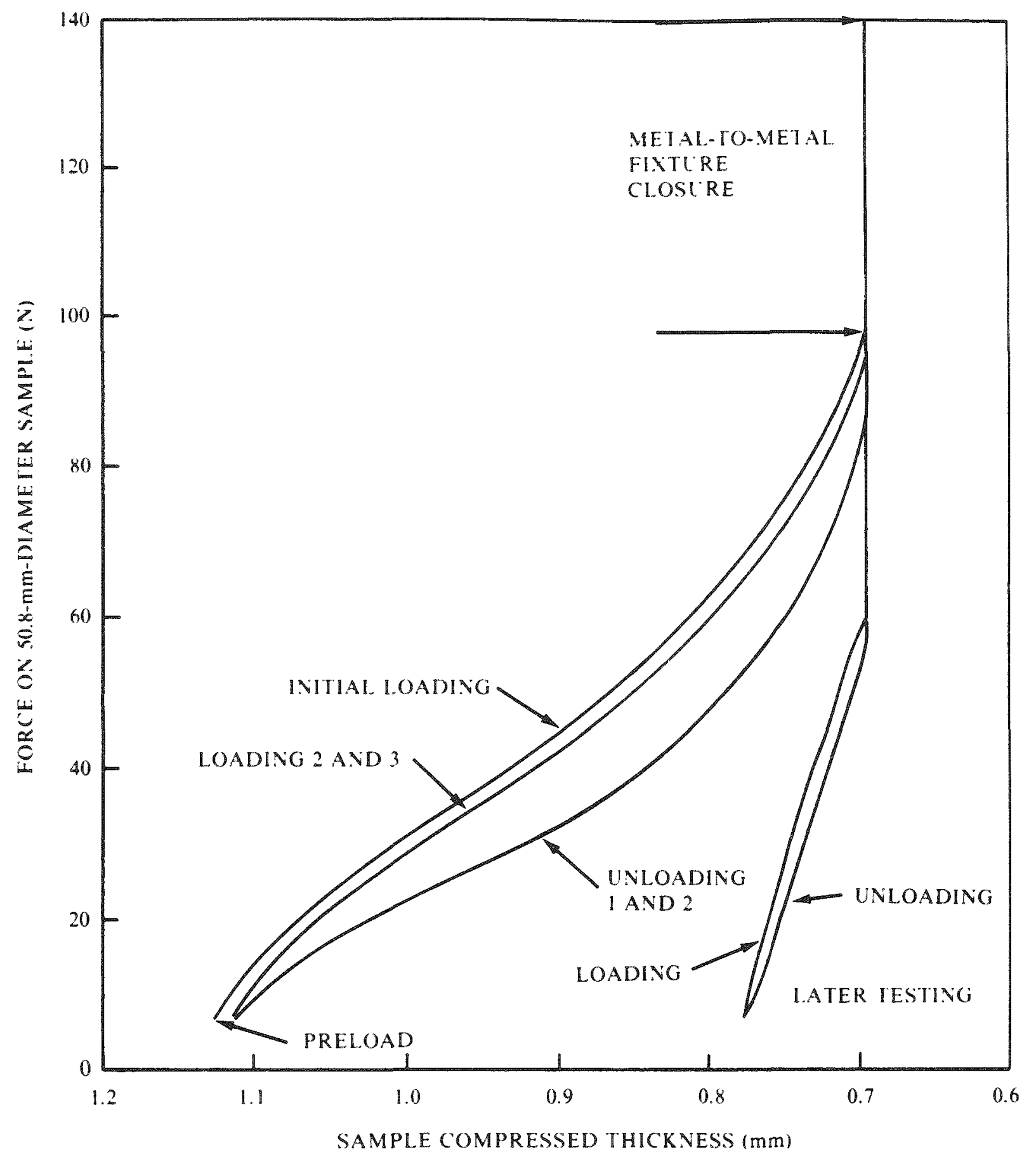

Figure 3. Typical Loading and Unloading Curves, Normal scale, at Initial Loading and Later Testing 


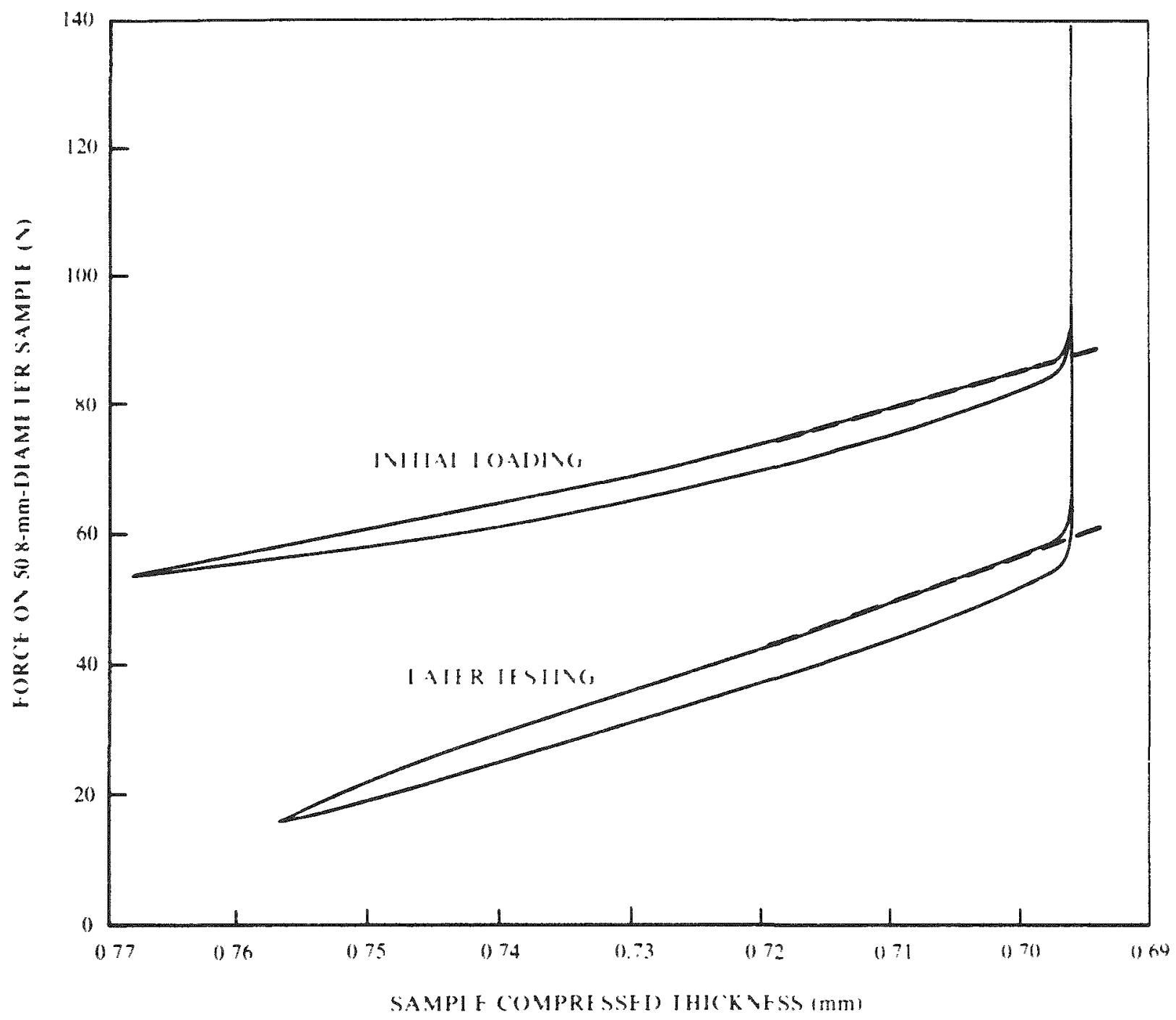

Figure 4. Typical Loading and Unloading Curves, Expanded Scale With Tangent Drawn, at Initial Loading and Later Testing

$\mathrm{Y}=\mathrm{M}^{*} \ln \mathrm{X}+\mathrm{B}$

where

$M=$ constant generated by the program;

$B=$ constant (intercept) generated by the program;

$X=$ time; and

$\mathrm{Y}=$ percent load retention.

This equation predicted a 10-year percent load retention of 64.30, which visually gives a better tit. The new equation was 
also used on the other material types. The new equation generated 10-year predictions that are within 1.5 percent of the original equation used. The statistical analysis system program that used the equation $Y=M * \ln X+B$ also generated an $R$-square value that is an indicator for how well the data fit the equation. The $R$-square values for the materials are shown in Table 1 .

A high $R$-square value is desired, since a value of 1.000 is a perfect fit. The equation $Y=M * \ln X+B$ will now be used to analyze the data in this report.

The trends are plotted together in Figure A-5. Table 2 contains data on the 10-year predicted percent load retention for the last 6 years.

Compressed thickness measurements at the minimum load were recorded as a side benetit. The measured values of the aged samples along with the measured values at assembly were used in a standard compression set formula. The value calculated previously was named effective compression set. These data are plotted versus the time in assembly (Figure $A-6$ ). All the data points were used to determine a least-squares approximation for each material type and density.

\section{ACCOMPLISHMENTS}

The predicted percent load retention values at the end of 10 years have insignificant increases for the equilibrium- and condensation-type material at both densities. The equilibriumtype material at $0.34 \mathrm{~g} / \mathrm{cm}^{3}$ has an increased 10 -year prediction by use of the different equation to analyze the data. The equilibrium-type material at $0.52 \mathrm{~g} / \mathrm{cm}^{3}$ exhibited an insignificant increase in the predicted value, corresponding closely to the condensation-type material results with the alternate equation.

The rate of the load loss for both densities of condensation-type material are now approximately the same.

A low load retention value usually corresponds to a high effective compression set value. The equilibrium-type material, which has the lowest percent load retention values, has the highest compression set, but the condensation-type materials are just the opposite. Currently, the predicted percent load retention is between 60 and 68 percent of original load. 
Table 1. R-Square Values for Various Materials

\begin{tabular}{lll}
\hline $\begin{array}{l}\text { Material } \\
\text { Type }\end{array}$ & Density & R Square \\
\hline Equilibrium & $0.34 \mathrm{~g} / \mathrm{cm}^{3}$ & 0.662 \\
Condensation & $0.34 \mathrm{~g} / \mathrm{cm}^{3}$ & 0.840 \\
Equilibrium & $0.52 \mathrm{~g} / \mathrm{cm}^{3}$ & 0.876 \\
Condensation & $0.52 \mathrm{~g} / \mathrm{cm}^{3}$ & 0.914 \\
\hline
\end{tabular}

Table 2. Ten-Year Predicted Percent Load Retention

\begin{tabular}{|c|c|c|c|c|}
\hline \multirow{2}{*}{$\begin{array}{l}\text { Year } \\
\text { Tested }\end{array}$} & \multicolumn{2}{|c|}{$0.34 \mathrm{~g} / \mathrm{cm}^{3}$ Density } & \multicolumn{2}{|c|}{$0.52 \mathrm{~g} / \mathrm{cm}^{3}$ Density } \\
\hline & Equilibrium & Condensation & Equilibrium & Condensation \\
\hline $\begin{array}{l}1979 \\
1980 \\
1981 \\
1982 \\
1983 \\
1984 \\
1984 \% \%\end{array}$ & $\begin{array}{ll}61.3 & (4) \\
57.38 & (5) \\
58.88 & (6) \\
60.04 & (7) \\
60.75 & (8) \\
61.36 & (9) \\
64.30 & (9)\end{array}$ & $\begin{array}{ll}67.16 & (3) \\
65.28 & (4) \\
65.94 & (5) \\
66.14 & (6) \\
66.50 & (7) \\
66.66 & (8) \\
67.60 & (8)\end{array}$ & $\begin{array}{ll}58.21 & (4) \\
57.41 & (5) \\
58.49 & (6) \\
58.92 & (7) \\
59.25 & (8) \\
59.34 & (9) \\
60.12 & (9)\end{array}$ & $\begin{array}{ll}63.99 & (3) \\
63.52 & (4) \\
64.13 & (5) \\
64.29 & (6) \\
64.65 & (7) \\
64.77 & (8) \\
65.29 & (8)\end{array}$ \\
\hline
\end{tabular}

*Approximate years of data used to generate predicted values. $*$ *redictions based on the equation $Y=M * I n X+B$.

FUTURE WORK

The samples will continue to be monitored yearly until completion of the 10-year plan. 


\section{REFERENCES}

1J. W. Schneider, Stress Relaxation of Cellular Silicone Material (Topical Report). Bendix Kansas City: BDX-613-2487, October 1980 (Available from NTIS).

$2 \mathrm{~J}$. W. Schneider, Stress Relaxation of Cellular Silicone Material (Topical Report). Bendix Kansas City: BDX-613-2399, May 1980 (Available from NTIS).

${ }^{3} \mathrm{~J}$. W. Schneider, Stress Relaxation of Cellular Silicone Material: 1981 (Topical Report). Bendix Kansas City: BDX-613-2645, September 1981 (Available from NTIS).

${ }^{4} \mathrm{~J}$. W. Schneider, Stress Relaxation of Cellular Silicone Material: 1982 (Topical Report). Bendix Kansas City: BDX-613-2784, June

$\overline{1982}$ (Available from NTIS).

${ }^{5} \mathrm{~J}$. W. Schneider, Stress Relaxation of Cellular Silicone Material: 1983 (Topical Report). Bendix Kansas City: BDX-613-3013, November 1983 (Available from NTIS). 
Appendix

PERCENT RETENTION VERSUS LOG TIME DATA 
FILP

EDIILIERIUA TYPE OS 34 G.CE NCMINAL DENSITY

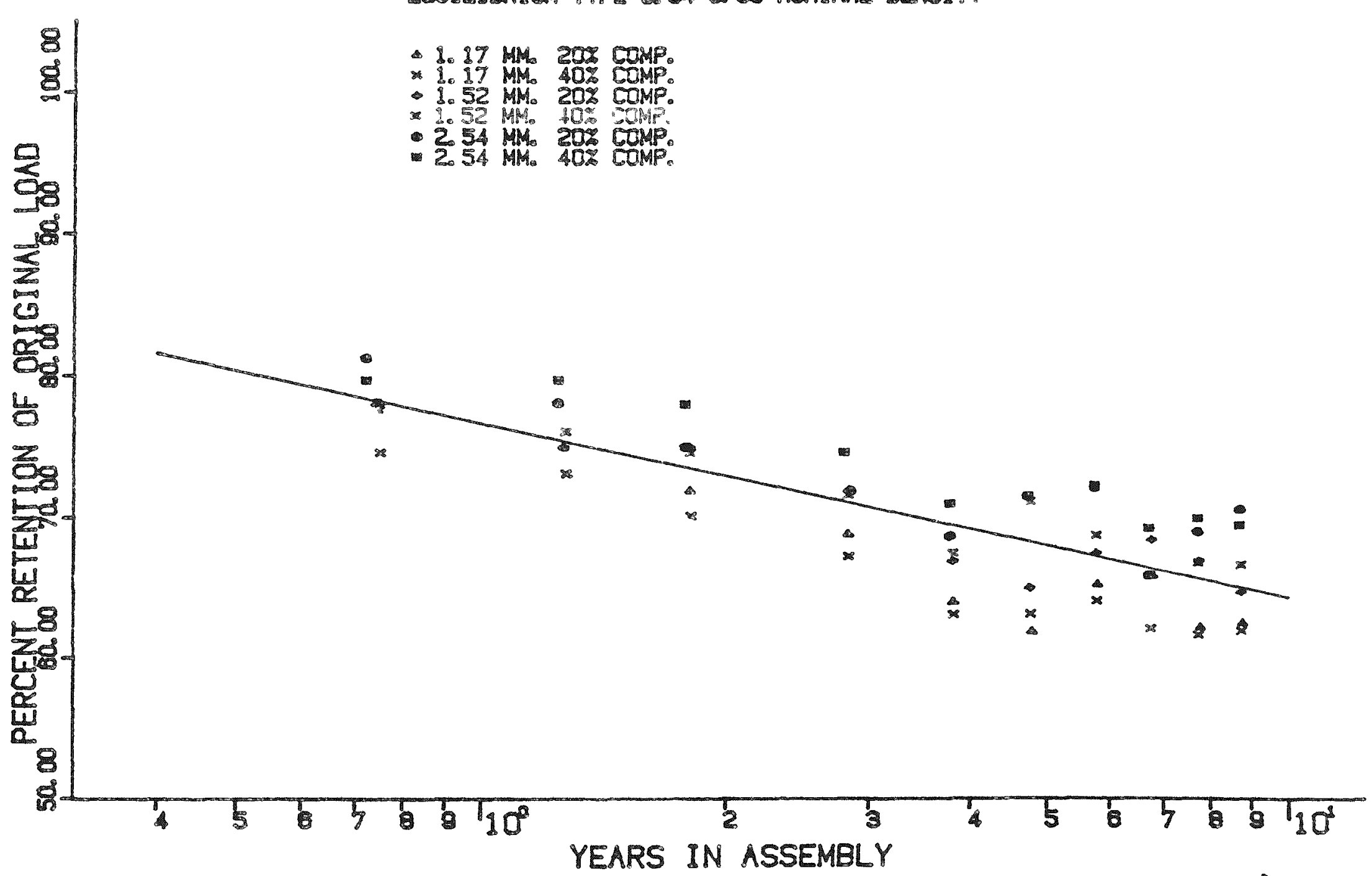

Figure A-1. Percent Rerenton Versus Log Tıme for Equilibrium-TI pe Material, 0.34 gin" Nominal Densicy 
Fgare

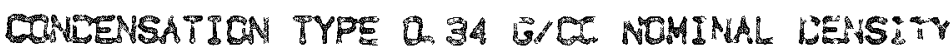

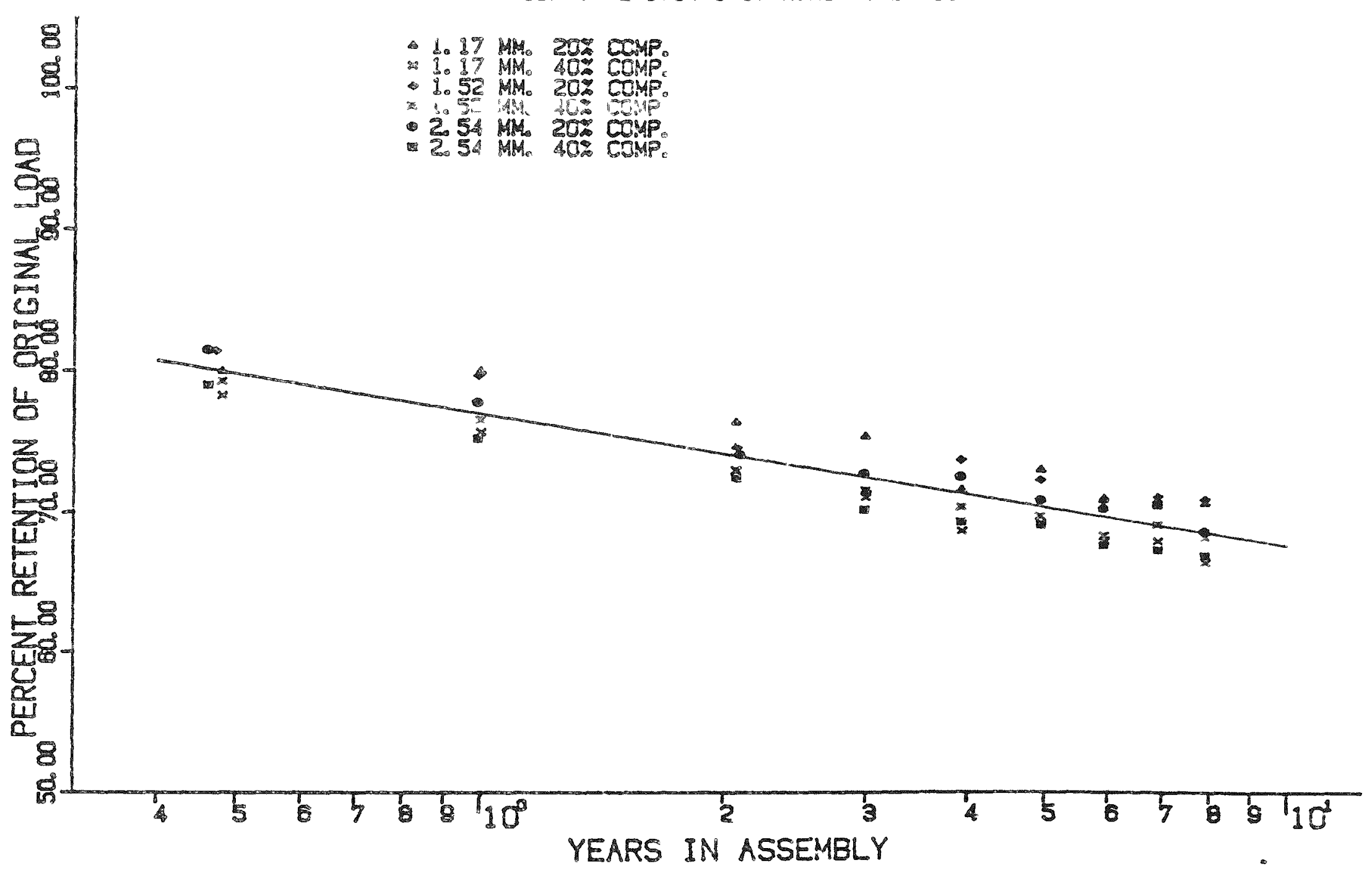

Figure A-2 Percent Retention versus Log Time for Condensatıon-Type Mucerial $034 \mathrm{~g}^{\prime} \mathrm{cm}^{3}$ 
Fone

EDUILIERIUA TYPE Q SE GCE NCMINAL TENSITY

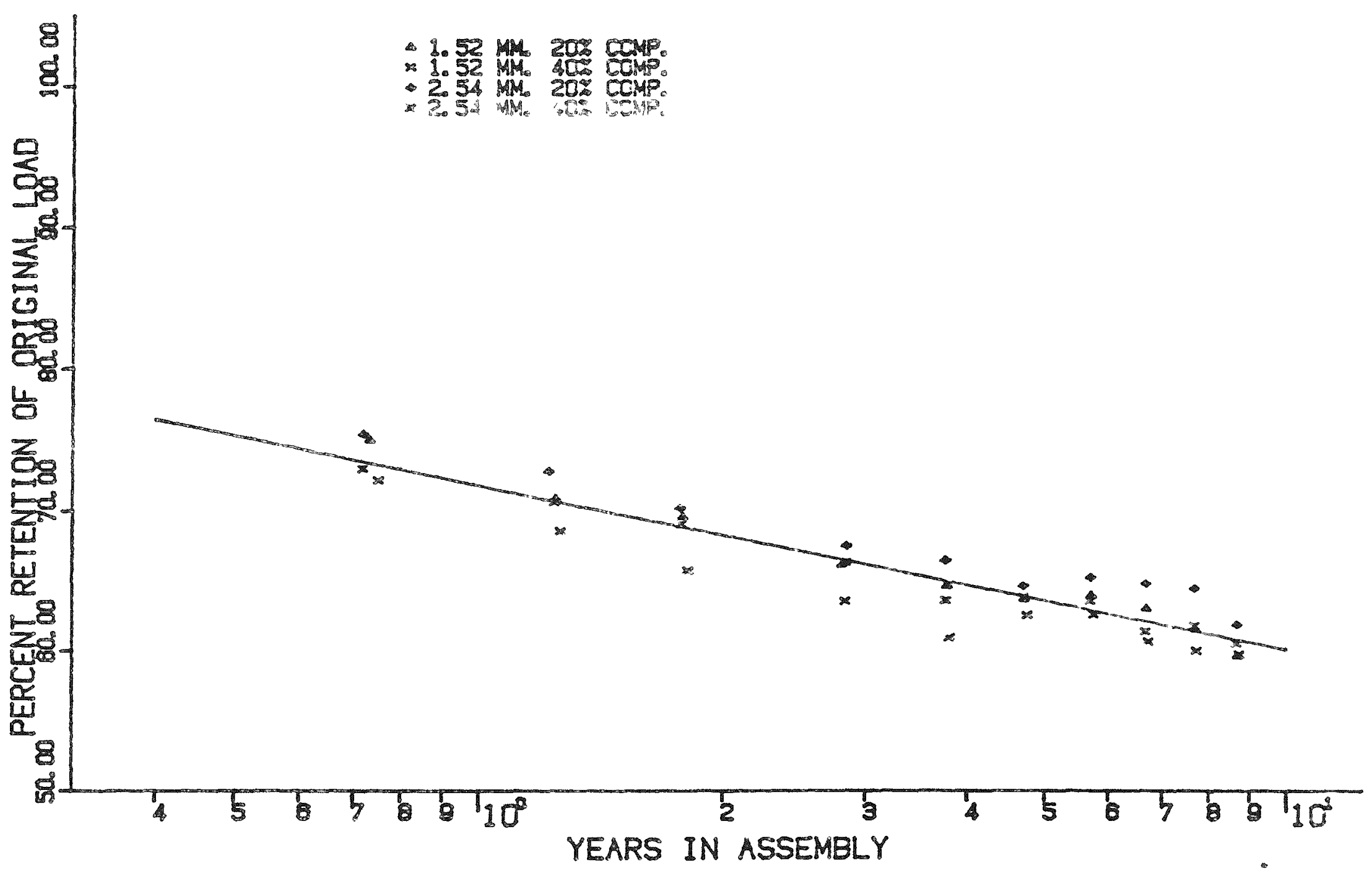

Figure A-3 Percent Rerencinn Versus Log Time for Equiliorium-Type gfacerial, $052 \mathrm{~g} \mathrm{~cm}^{3}$ Nominal Density 
Pมี⿻

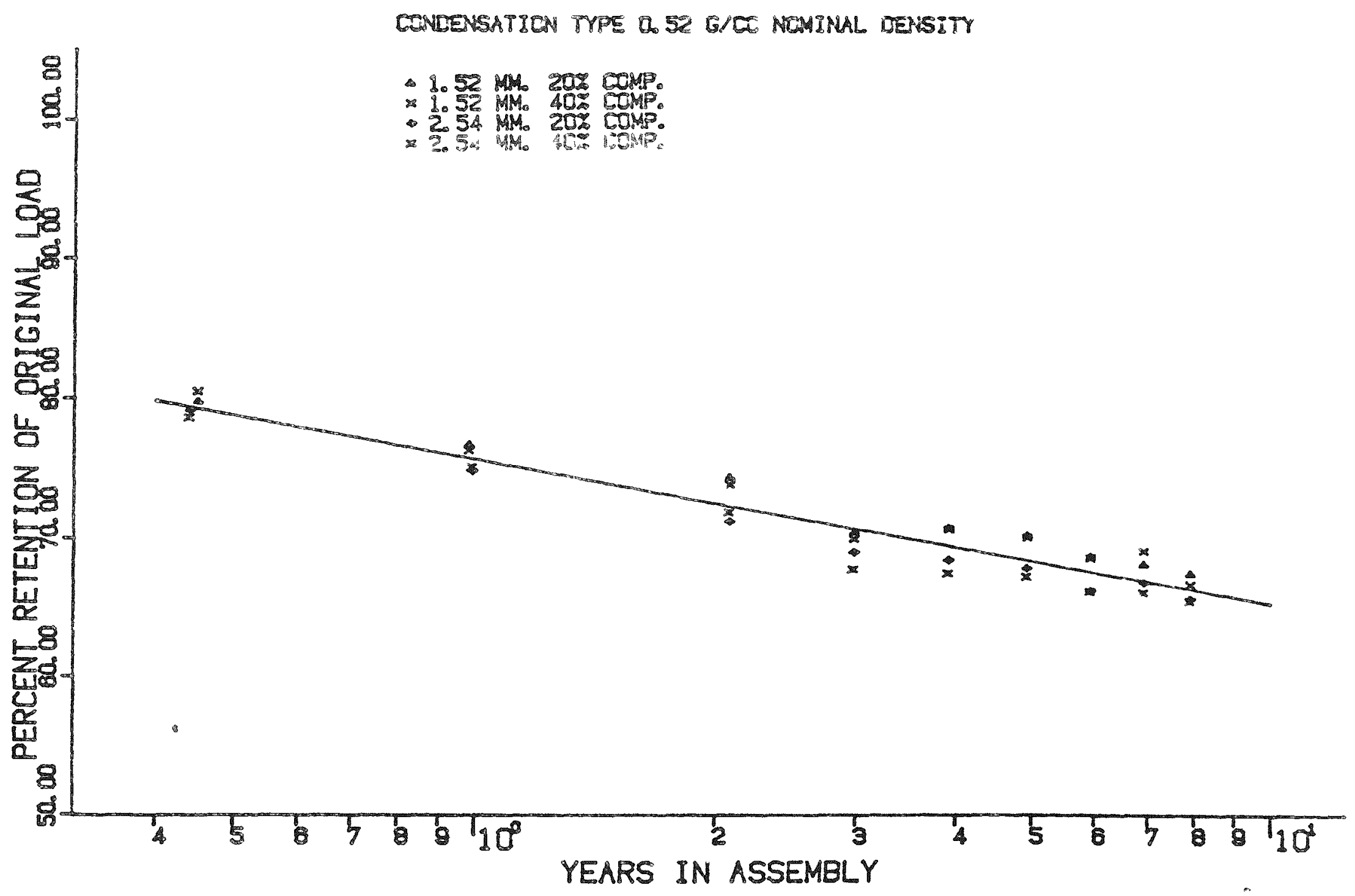

Figure A-4. Percent Recention Versus Log Time for Condensation-Type Material, $0.52 \mathrm{~g} / \mathrm{cm}^{3}$ 
Fรas:

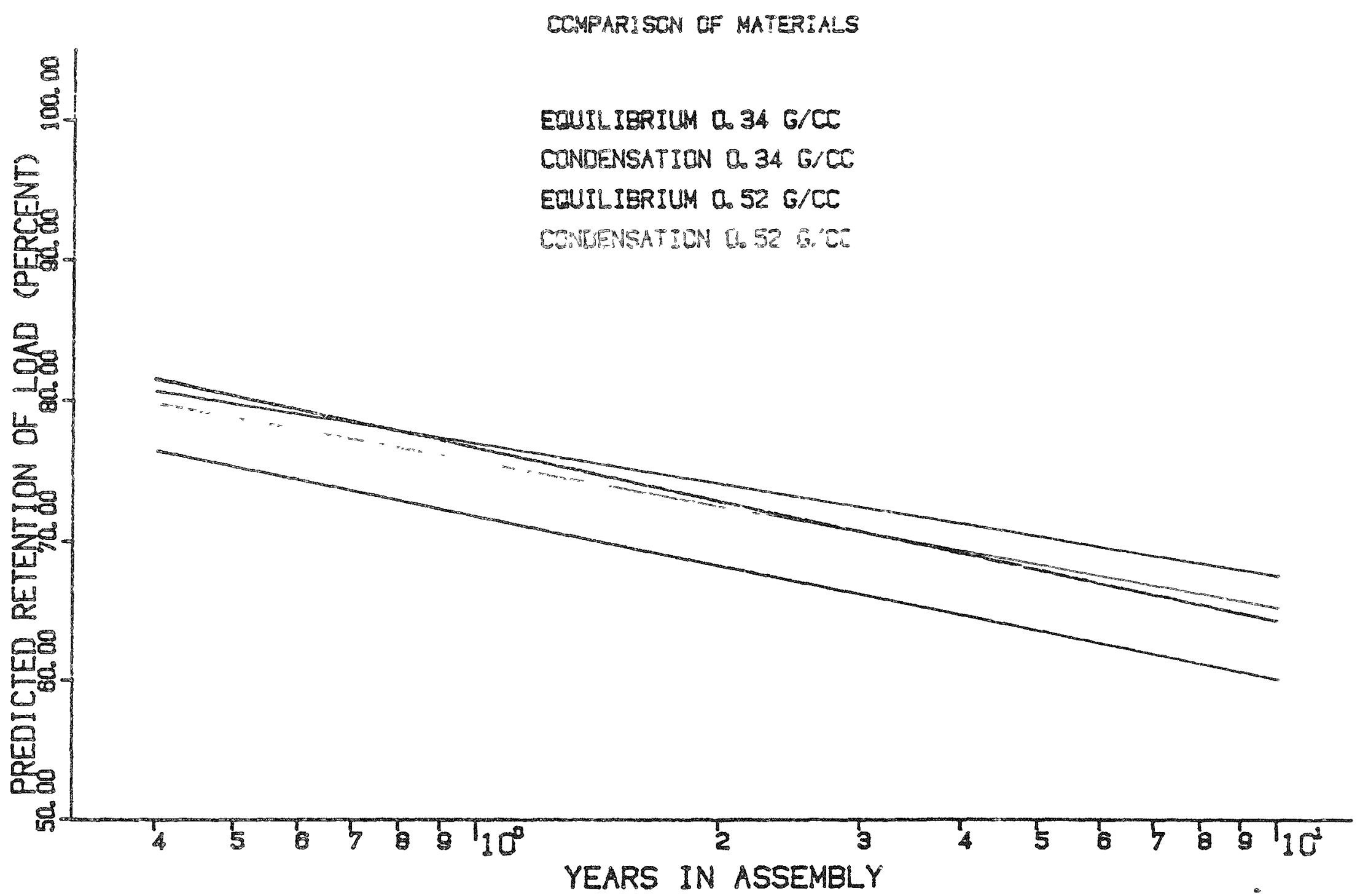

Figure A-5 Percent Retention Versus Log Time, Comnarison of Materials 
Fane $\$ 0$

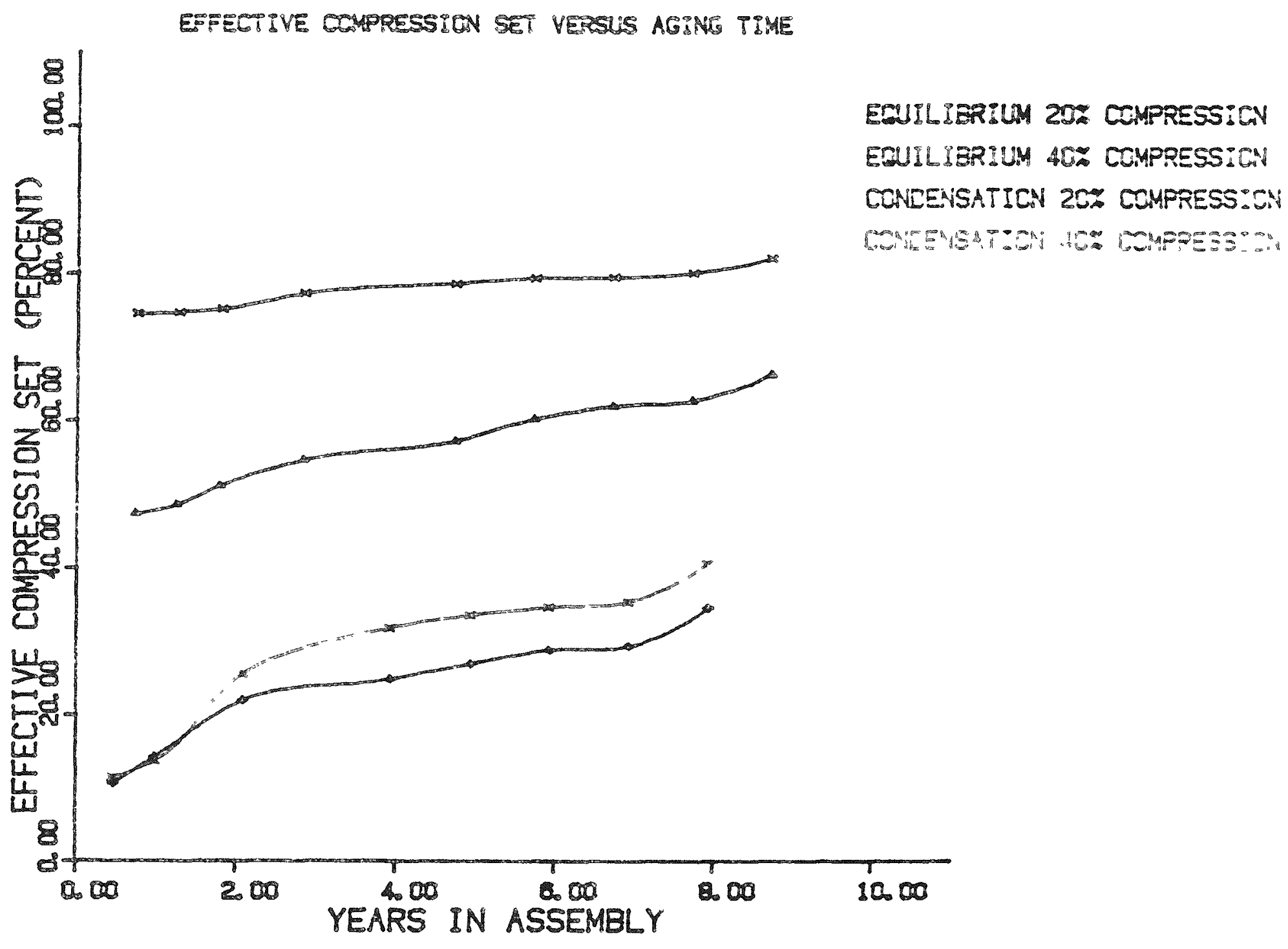

Figure A-6. Effective Compression Set Versus Aging Time 